\title{
Molecular identification of Atlantic goliath grouper Epinephelus itajara (Lichtenstein, 1822) (Perciformes: Epinephelidae) and related commercial species applying multiplex PCR
}

\author{
Júnio S. Damasceno ${ }^{1,2}$, Raquel Siccha-Ramirez ${ }^{3,4}$, Claudio Oliveira ${ }^{3}$, Fernando \\ F. Mendonça ${ }^{5}$, Arthur C. Lima ${ }^{6}$, Leonardo F. Machado ${ }^{3,7}$, Vander C. Tosta \\ Ana Paula C. Farro ${ }^{7}$ and Maurício Hostim-Silva ${ }^{7}$
}

The Atlantic goliath grouper, Epinephelus itajara, is a critically endangered species, threatened by illegal fishing and the destruction of its habitats. A number of other closely related grouper species found in the western Atlantic are also fished intensively. While some countries apply rigorous legislation, illegal harvesting followed by the falsification of fish products, which impedes the correct identification of the species, is a common practice, allowing the catch to be marketed as a different grouper species. In this case, molecular techniques represent an important tool for the monitoring and regulation of fishery practices, and are essential for the forensic identification of a number of different species. In the present study, species-specific primers were developed for the Cytochrome Oxidase subunit I gene, which were applied in a multiplex PCR for the simultaneous identification of nine different species of Epinephelidae: Epinephelus itajara, E. quinquefasciatus, E. morio, Hyporthodus flavolimbatus, H. niveatus, Mycteroperca acutirostris, M. bonaci, M. marginata, and M. microlepis. Multiplex PCR is a rapid, reliable and cost-effective procedure for the identification of commercially-valuable endangered fish species, and may represent a valuable tool for the regulation and sustainable management of fishery resources.

O mero, Epinephelus itajara, encontra-se criticamente ameaçado, resultado da pesca ilegal e destruição dos habitas. Filogeneticamente relacionadas a este táxon encontram-se garoupas que atualmente são intensamente pescadas no Atlântico Oeste. Apesar de leis mais restritivas aplicadas em alguns países, a captura ilegal com a descaracterização morfológica é uma prática comum que impossibilita a identificação correta da espécie permitindo que seja comercializada como garoupas, badejos ou chernes. A este respeito, técnicas moleculares representam ferramentas importantes para o monitoramento e fiscalização da pesca, provando ser essencial, na identificação forense de diversas espécies. Primers espécie-específicos foram desenvolvidos com base no gene Citocromo Oxidase subunidade I que aplicados em PCR-Multiplex possibilitam a identificação simultânea de nove espécies Epinephelidae: Epinephelus itajara, E. quinquefasciatus, E. morio, Hyporthodus flavolimbatus, H. niveatus, Mycteroperca acutirostris, M. bonaci, M. marginata e M. microlepis. A identificação via PCR multiplex de espécies de peixes ameaçadas e comercialmente importantes é um método rápido, prático, seguro e de baixo custo, que poderá ser útil o controle do uso e manejo sustentável de recursos pesqueiros.

Keywords: Conservation genetics, COI, Endangered species, Fishery management, Forensic genetics

\footnotetext{
${ }^{1}$ Programa de Pós-graduação em Oceanografia Ambiental, Departamento de Oceanografia e Ecologia, Base Oceanográfica, Universidade Federal do Espírito Santo (UFES), Rodovia ES 10 km 16, 565, Coqueiral, 29199-970 Aracruz, ES, Brazil. jdamascenobh@gmail.com (corresponding author) ${ }^{2}$ Programa de Pós-graduação em Biologia de Vertebrados, Laboratório de Genética da Conservação, PUCMINAS - Pontifícia Universidade Católica de Minas Gerais, Av. Dom José Gaspar 500, Coração Eucarístico, 30535-901 Belo Horizonte, MG, Brazil

${ }^{3}$ Laboratório de Biologia e Genética de Peixes, Departamento de Morfologia, Instituto de Biociências de Botucatu, Universidade Estadual Paulista (UNESP), Distrito de Rubião Junior, s/n, 18618-000 Botucatu, SP, Brazil. (RSR) zsiccha@imarpe.gob.pe, (CO) claudio@ibb.unesp.br ${ }^{4}$ Laboratorio Costero de Tumbes, Instituto del Mar del Perú (IMARPE), Calle José Olaya S/N, Nueva Esperanza, Zorritos, TU, Perú

${ }_{5}^{5}$ Departamento de Ciências do Mar, Instituto do Mar, Universidade Federal de São Paulo (UNIFESP), Av. Alm. Saldanha da Gama, 89, Ponta da Praia, 11030-400 Santos, SP, Brazil. (FFM) fernandoffm@yahoo.com.br

${ }^{6}$ Costa Lima Aquicultura e Pesca, Praça Prefeito José Luiz da Costa, 27, Centro, 29960-000 Conceição da Barra, ES, Brazil. (ACL) aclpesca@yahoo.com.br

${ }^{7}$ Departamento de Ciências Agrárias e Biológicas, Universidade Federal do Espírito Santo (UFES), Rodovia BR 101 Norte, Km 60, Litorâneo, 29932-540 São Mateus, ES, Brazil. (LFM) dusky.grouper@gmail.com, (VCT) calmontosta@gmail.com, (APCF) farro.ana@ gmail.com, (MHS) mhostim@gmail.com
} 


\section{Introduction}

The increasing demand for fishery resources has led to the gradual, worldwide collapse of stocks in marine ecosystems, leading to the substitution of preferred species by smaller, short lived ones, in increasingly simplified trophic networks (Pauly et al. 2002). These larger-bodied, preferred species include groupers (Epinephelidae) and snappers (Lutjanidae), which are associated with reef habitats, are highly valued commercially, but are extremely vulnerable to fishery pressure (Begossi et al., 2012a).

Epinephelidae is a group of reef fishes comprising more than 160 species distributed in 16 genera. The greatest diversity of epinephelids is found in the Indo Pacific region, and the eastern Atlantic is the probable center of dispersal of all the epinephelid groupers in the mid-Eocene (Ma, 2014). The present day fauna of the western Atlantic includes about 25 species of the family Epinephelidae, arranged in eight genera (Craig et al., 2011).

The Atlantic goliath grouper, Epinephelus itajara (Lichtenstein, 1822), is the largest grouper species (> $400 \mathrm{~kg}$ ) found in the Atlantic Ocean, and is listed by the IUCN as "critically endangered", due to population decline resulting from overfishing and habitat degradation (Craig, 2011; IUCN, 2015). This grouper is found in tropical and subtropical waters of the western Atlantic, between Florida and southern Brazil, including the Gulf of Mexico and the Caribbean, as well as the west coast of Africa, between the Congo and Senegal (Francesconi \& Schwartz, 2000; Craig et al., 2011).

The Brazilian coast is considered to be a conservation hotspot for the reef dwelling epinephelids, where resident species include Epinephelus itajara, Mycteroperca marginata (Lowe, 1834) (endangered: IUCN, 2015), Hyporthodus flavolimbatus (Poey, 1865) and H. niveatus (Valenciennes, 1828) (vulnerable: IUCN, 2015), E. morio (Valenciennes, 1828) and M. bonaci (Poey, 1865) (near threatened: IUCN, 2015). Species such as M. microlepis (Goode \& Bean, 1879), which has a declining population, and M. acutirostris (Valenciennes, 1828), which is vulnerable to overfishing (Begossi et al., 2012a; 2012b; Sadovy de Mitcheson et al., 2013), also demand attention. The species E. itajara, E. morio, H. flavolimbatus, H. niveatus and $M$. microlepis in particular have been threatened by overfishing in recent decades along practically the whole of the tropical and subtropical coastal regions of the western Atlantic (Graham et al., 2009; Coleman \& Koenig, 2010; Sadovy de Mitcheson et al., 2013).

Despite the prohibition of fishing in 2002, the capture and sale of Atlantic goliath grouper has been recorded frequently by the authorities, with a mean annual catch of more than 330 tons between 2003 and 2011 (IBAMA, 2004; 2005; 2007a; 2007b; 2008; MPA, 2012a; 2012b; 2012c). Considering also the lack of data on artisanal fisheries, together with the common practice of disguising catches, it seems likely that the Brazilian populations of
Atlantic goliath grouper are impacted severely by fisheries, irrespective of the established conservation legislation.

Genetic tools for the molecular identification of a number of different fish species have been developed during the past decade (Ward et al., 2005; Craig et al., 2009; Hashimoto et al., 2010; Rodrigues et al., 2011; Alexandre de-Franco et al., 2012; Ulrich et al., 2013; Veneza et al., 2014). Carvalho et al. (2015) has shown the DNA barcoding to be an effective molecular tool for the detection of commercially-valuable species such as the groupers, while Torres et al. (2013) successfully applied PCR RFLP and SNP detection techniques to the identification of specimens of E. itajara, E. morio, $M$. bonaci, and M. marginata. The multiplex PCR technique, based on the COI gene (De-Franco et al., 2010; Mendonça et al., 2010) and other mitochondrial (Trotta et al., 2005; Hashimoto et al., 2010; Ravago-Gotanco et al., 2010) and nuclear genes (Shivji et al., 2002; Chapman et al., 2003; Rodrigues et al., 2011), has proven to be an efficient and rapid low-cost tool that is safe and easy to apply (Abercrombie et al., 2005). This technique permits the identification of illegal fishing by the authorities, even when the catches have been processed for consumption, and contribute to conservation practices on a worldwide scale (Mendonça et al., 2010).

Large-bodied fishes such as groupers (Epinephelidae), which inhabit reef ecosystems around the world, have a high commercial value and are intensively exploited, although their biological characteristics, such as their longevity, late sexual maturation, and breeding aggregations, that make them especially vulnerable to overfishing (Sadovy \& Eklund, 1999; Chiappone et al., 2000; Pauly et al., 2002; Sadovy de Mitcheson et al., 2013). Industrialization of fisheries has led to a sharp decline in the marine wildlife, which will require the adequate management and controls to ensure that currently environmental alterations do not result in a complete collapse of fishery stocks (McCauley et al., 2015).

Considering the urgent need to conserve groupers stocks and the importance of identifying these species where illegal harvesting is disguised by the falsification of fish products, the present study aimed to develop a rapid, simple, and low-cost procedure characteristics of the COI gene to discriminate nine species of epinephelids.

\section{Material and Methods}

A total of 35 samples were obtained from specimens belonging to three genera (Epinephelus, Mycteroperca, and Hyporthodus) and nine grouper species: E. itajara $(\mathrm{N}=8$ specimens), E. quinquefasciatus $(\mathrm{N}=5)$, E. morio $(\mathrm{N}=2)$, H. flavolimbatus $(\mathrm{N}=1)$, H. niveatus $(\mathrm{N}=6), M$. acutirostris $(\mathrm{N}=2), M$. bonaci $(\mathrm{N}=4), M$. marginata $(\mathrm{N}=6)$, and $M$. microlepis $(\mathrm{N}=1)$. The specimens were identified from their morphological characteristics, following Heemstra \& Randall (1993) and Craig et al. (2011). 
The specimens obtained from fish markets at a number of different localities around the coast of Brazil, and were captured by fishing vessels operating off the coast of Santa Catarina, Espírito Santo, southern Bahia, and Paraíba. The specimens of E. itajara were obtained from the states of Pernambuco, Sergipe, Bahia, Espírito Santo, and Santa Catarina using traditional fish traps, with samples of the tail fin being extracted using a non-lethal procedure. Once the samples were collected, the E. itajara specimens were weighed, measured, marked, and released back into the area where they were caught. The samples were preserved in $95 \%$ ethanol and stored in a freezer at $-20^{\circ} \mathrm{C}$.

Given the evolutionary proximity of the Atlantic and Pacific goliath groupers (Craig et al., 2009), samples of Epinephelus quinquefasciatus (Bocourt, 1868), which is endemic to the eastern Pacific, were obtained from fisheries in Puerto Sandino, Nicaragua. These samples were used to validate the results of the multiplex PCR and guarantee the reliability of the analysis of the epinephelid species.

Extraction, Amplification and Sequencing of the DNA. The genomic DNA was extracted using the method described by Aljanabi \& Martinez (1997). The amplification reactions for the COI were run in an Applied Biosystems ${ }^{\circledR}$ Veriti ${ }^{\circledR} 96$ Well Fast thermal PCR cycler, using $25 \mu \mathrm{l}$ of solution containing $0.8 \mathrm{mM}$ of $\mathrm{dNTP}$ (Invitrogen $\AA$ ), 1.5 $\mathrm{mM}$ of $\mathrm{MgCl}_{2}$, Taq DNA polymerase enzymatic buffer (Tris-HCl $20 \mathrm{mM}$ at $\mathrm{pH} 8.4$ and $\mathrm{KCl} 50 \mathrm{mM}$ ), 1 unit of Taq Polymerase enzyme (PHT Phoneutria $\left.{ }^{\circledR}\right)$, and $5 \mu \mathrm{M}$ of each universal primer, F1 5" TCA ACC AAC CAC AAA GAC ATT GGC AC 3" and R1 5" TAG ACT TCT GGG TGG CCA AAGAAT CA 3" (Ward et al., 2005). Each PCR amplification cycle consisted of denaturation at $96^{\circ} \mathrm{C}$ for $30 \mathrm{~s}$, hybridization at $52^{\circ} \mathrm{C}$ for $30 \mathrm{~s}$, and extension at $68^{\circ} \mathrm{C}$ for $1 \mathrm{~min}$, repeated 35 times. The DNA segments were visualized in agarose gel in TAE $1 \mathrm{X}$ (Tris-Acetate EDTA) using GelRed (Biotium ${ }^{\circledR}$ ) under a MacroVue UV25 (Hoefer ${ }^{\circledR}$ ) ultraviolet transilluminator. Sequencing was conducted using the BigDye Terminator kit, according to the maker's recommendations (Applied Biosystems ${ }^{\circledR}$ ). The samples were precipitated with $0.7 \mathrm{uL}$ of EDTA $(125 \mathrm{mM}), 0.7 \mathrm{uL}$ of sodium acetate $(3 \mathrm{M})$ and $25 \mathrm{uL}$ of ethanol (100\%), then washed in $35 \mathrm{uL}$ of $70 \%$ ethanol and the containers were dried at $95^{\circ} \mathrm{C}$ for 8 minutes before sequencing in the ABI Prism 3130 (Applied Biosystems ${ }^{\circledR}$ )

Multiplex PCR. Nine species-specific primers were designed based on the exclusive polymorphic sites of the COI gene found in each of the study species (Table 1), which were used in combination with the primers F1 and R1 (Ward et al., 2005). All the COI amplification reactions based on the species-specific primers were run in a thermal cycler with $25 \mu \mathrm{l}$ of solution containing $0.8 \mathrm{mM}$ of dNTP (Invitrogen $\AA$ ), $1.5 \mathrm{mM}$ of $\mathrm{MgCl}_{2}$, Taq DNA polymerase enzymatic buffer (Tris- $\mathrm{HCl} 20 \mathrm{mM}$ at $\mathrm{pH} 8.4$ and $\mathrm{KCl} 50$ $\mathrm{mM}$ ), 1 unit of Taq Polymerase enzyme (PHT Phoneutria ${ }^{\circledR}$ ), and $5 \mu \mathrm{M}$ of each specific primer. The amplification and visualization of the sequences followed the same protocol used for the F1 and R1 primers.

Analyses. The sequences were aligned using the Muscle program, available online at www.ebi.ac.uk/Tools/msa/ muscle/ (Edgar, 2004). The taxon's phylogram was analyzed in Mega 5.2 (Tamura et al., 2011) using the Neighbour Joining (NJ) method based on the Kimura 2 parameter model (Kimura, 1980), and tested using the bootstrap method with 1000 pseudoreplications (Felsenstein, 1981). The identification of the species based on the $\mathrm{COI}$ sequences was confirmed by blasting against the GenBank database (http://blast.ncbi.nlm.nih.gov/Blast. cgi). To guarantee the quality of the haplotypes, they were blasted using MegaBLAST of the GenBank database to minimize the use of sequences with inverted amplification of translocated nuclear copies of the mitochondrial DNA (numts), as recommended by Song et al. (2008), with only the sequences that were $99 \%$ or $100 \%$ similar to the species analyzed.

Table 1. Species-specific primers developed for the present study, the size of the fragments isolated, and the GenBank accession numbers of the sequences obtained for the nine grouper species of the family Epinephelidae. 1. Epinephelus quinquefasciatus 2. Epinephelus morio 3. Epinephelus itajara 4. Hyporthodus flavolimbatus 5. Mycteroperca microlepis 6. Mycteroperca bonaci 7. Mycteroperca marginata 8. Hyporthodus niveatus 9. Mycteroperca acutirostris.

\begin{tabular}{cccclc}
\hline Species & Code & Size of the fragment & Annealing temperature $\left({ }^{\circ} \mathrm{C}\right)$ & Primer & GenBank access number \\
\hline 1 & Eqi-COI & 644 & 51 & 5'- TAT TTG GTG CCT GGG CTG GA -3' & KF836472 \\
2 & Emo-COI & 539 & 51 & 5'- TAA TTG TTA CAG CGC ATG CA -3' & KF836470 \\
3 & Eit-COI & 478 & 51 & 5'- GGC TTT GGA AAT TGA CTT G -3' & KF836456 \\
4 & Hfl-COI & 341 & 51 & 5'- CTG GTA CTG GCT GAA CAG TT -3' & KF836477 \\
5 & Mmi-COI & 287 & 51 & 5'- GGG CAT CTG TAG ACT TAA CC -3' & KF836490 \\
6 & Mbo-COI & 233 & 53 & 5'- CTA GGG GCA ATT AAC TTC -3' & KF836486 \\
7 & Ema-COI & 146 & 53 & 5'- CCG TAC TAA TTA CCG CAG TC -3' & KF836464 \\
8 & Hng-COI & 95 & 53 & 5'- CGC CGG TAT TAC AAT GCT ATT G -3' & KF836478 \\
9 & Mac-COI & 50 & 56 & 5'- TCT TTG ATC CAG CAG GAG GC -3' & KF836484 \\
\hline
\end{tabular}


Phylogram included sequences from the GenBank database of other species of commercially-important reef-dwelling fishes belonging to the families Epinephelidae [e.g., Cephalopholis fulva (Linnaeus, 1758) and Hyporthodus nigritus (Holbrook, 1855)], and Polyprionidae [e.g., Polyprion americanus). These species were included to certify the separation of the specific taxa identified from the samples collected during the present study. Polyprion americanus is an endangered species, which was included in the tree because it has been identified in categories of fish similar to the other epinephelid species (Asensio, 2008; Bertoncini et al., 2013).

The set of primers designed during this study amplified fragments of different sizes (number of base pairs) of the mitochondrial DNA for each of the epinephelid species. In the multiplex PCR, the species specific primers (forward) designed in the present study were used together in the same reaction with the universal primers (F1 and R1) described by Ward et al. (2005). The size of the fragments produced for each species is shown in Table 1.

The species-specific primers were initially tested on a set of species samples to test their effectiveness for a standard PCR. The sequences amplified corresponded to the primers designed for each species. The different groups of samples were then tested together to identify possible incorrect amplifications.

\section{Results}

Amplification of the COI gene resulted in a fragment of 655 base pairs (bp) in all nine epinephelid species analyzed, with a mean nucleotide composition of $31.0 \%$ Thymine (T), 27.1\% Cytosine (C), 24.1\% Adenine (A), and $17.8 \%$ Guanine $(\mathrm{G})$. The phylogram constructed for commercially-important epinephelids and Polyprion americanus (Polyprionidae) was based on COI sequences with a sequence of $622 \mathrm{bps}$. In this analysis, the separation of the species was supported by high bootstrap values (Fig. 1).

The phylogram indicates that the differentiation of the taxa using the genetic sequences was adequate for the separation of the species. The genera Mycteroperca, Hyporthodus, Epinephelus and Cephalopholis formed distinct clades and Polyprion americanus was confirmed as the outgroup. The robustness of the phylogram is also confirmed by the identification of E. quinquefasciatus as the sister group of E. itajara.

Different size of the fragments of DNA generated using the species-specific primers were analyzed after the electrophoretic reaction, which showed the formation of different bands for each species located in different positions of the gel. The positive control of the reaction was indicated by the $\mathrm{F} 1$ and $\mathrm{R} 1$ primers of the $\mathrm{COI}$ gene, which has approximately 655 bps (Fig. 2). The results indicated that the samples of the different species were amplified by their species-specific primers when applied together in the multiplex PCR. No false positives were found when samples of other fish species were analyzed, indicating only the amplification of the band of the positive control of the COI gene.

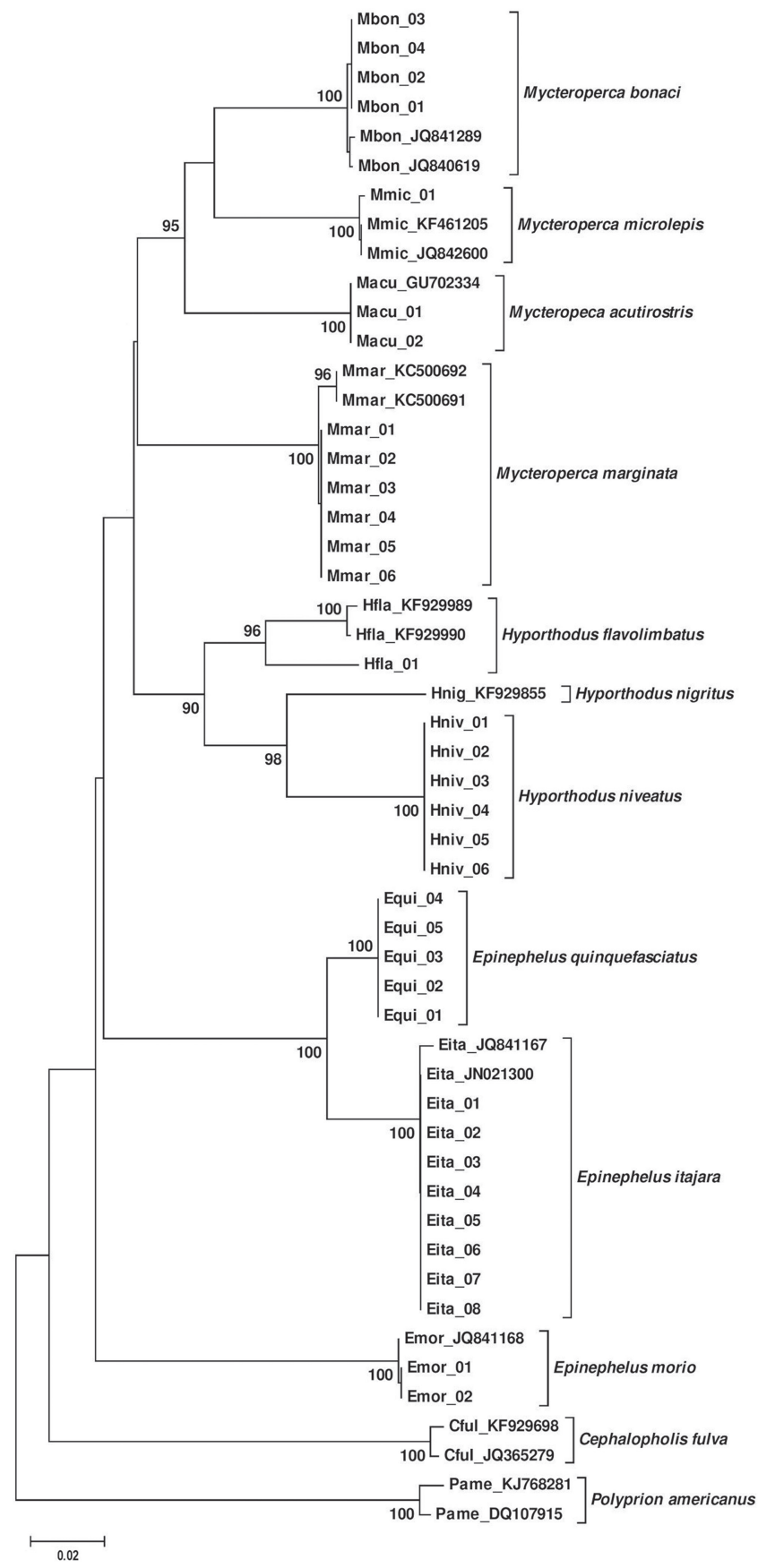

Fig. 1. Phylogram based on the amplification of the sequence of the Cytochrome Oxidase I gene of the commerciallyexploited species of fishes of the families Epinephelidae and Polyprion americanus (Polyprionidae). The samples collected in the present study are underlined and those obtained from the GenBank database appear together with their accession numbers. 


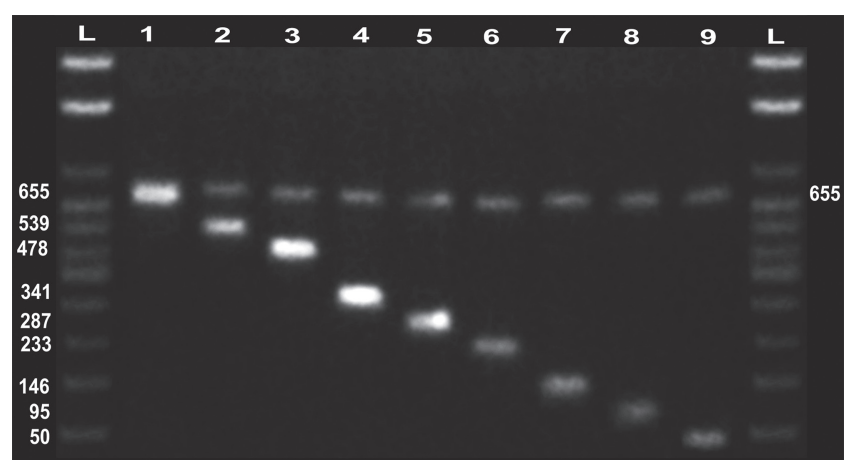

Fig. 2. Results of the electrophoresis of the universal COI fragment (655 bp) of grouper species of the family Epinephelidae. 1. Epinephelus quinquefasciatus, 2. E. morio, 3. E. itajara, 4. Hyporthodus flavolimbatus, 5. Mycteroperca microlepis, 6. M. bonaci, 7. M. marginata, 8. H. niveatus and 9. M. acutirostris. L. Molecular ladder. Fragment sizes: 1200, 1000, 700, 600, 500, 450, 400, 350, 250, 150, 50 bp (Electrophoresis: $1 \%$ agarose, $100 \mathrm{~V}, 100$ $\mathrm{mA}, 90$ minutes).

\section{Discussion}

Formation of specific clades in the congeneric groups (Epinephelus, Hyporthodus and Mycteroperca) based on the COI gene was similar to the phylogenetic arrangement described by Craig \& Hastings (2007) in a molecular study of the Epinephelidae. This emphasizes the reliability of the COI mitochondrial marker for the identification of the species of the family Epinephelidae.

The primers developed here generated distinct patterns of amplification in the multiplex PCR, producing electrophoretic bands of different molecular weights for each of the nine grouper species (Epinephelidae). The use of these primers to discriminate the study species permits considerable savings of time and laboratory work (Teletchea, 2009). Species-specific primers provide lowcost, practical molecular tools that may contribute to the reliable identification of commercial species. This tool has the additional advantage, especially in the context of developing countries, of being relatively easily applied (Abercrombie et al., 2005). The molecular techniques currently available have amplified the perspectives for the application of basic genetic tools to the conservation and management of endangered species in these nations (Bestervan der Merwe \& Gledhill, 2015).

Despite being a protected species in Brazil, Epinephelus itajara is subject to illegal commercial fishing along the coast. While the local fishermen are aware of the law prohibiting the exploitation of a number of species, the lack of any effective regulation or controls by government authorities probably encourages illegal fishing (Alexandre de-Franco et al., 2012). The reliable regulation and management of fisheries depends on the adequate identification of the target species and their byproducts. The incorrect identification of fishery products raises a number of concerns, from both economic (fraud) and environmental perspectives, i.e., the management of stocks, due to the reduction in public confidence in the system responsible for the regulation of the fishery industry, and the prevention of the illegal exploitation of protected species (Ogden 2008; Melo Palmeira et al., 2013). In this context, genetic markers capable of discriminating E. itajara represent a valuable tool for the regulation of the fishery industry, and the establishment of a reliable system for the application of the legislation prohibiting the commercial exploitation of this species.

Species-specific primers tool available from this study can also ensure the collection of reliable fishery statistics, which are necessary for the development of effective management and regulatory measures, as well as the conservation of overfished and endangered species (Baker, 2008; Alacs et al., 2010). This question is especially relevant in Brazil, where fishery statistics are largely unreliable and limit the understanding of the commercial exploitation of epinephelids. In fact, official reports often lump together species of the genera Epinephelus, Hyporthodus, and Mycteroperca, and may even include members of other families, such as Polyprion americanus (Bloch \& Schneider, 1801), even though this polyprionid is classified as endangered in the IUCN Red List (2015). The inaccurate identification of catches and the marketing of counterfeit fishery products represent a serious threat to the conservation of commercially-valuable fishes such as the groupers, i.e., the Epinephelidae (Asensio, 2008; Carvalho et al., 2015).

The impact of illegal fishing on the Atlantic goliath grouper is of increasing concern due to the distribution of the species in coastal habitats that suffer intensifying anthropogenic pressure, as well as the intrinsic characteristics of the species, such as its longevity, slow sexual maturation, and in particular its habit of forming breeding aggregations that facilitate fishery operations (Sadovy \& Eklund, 1999; Sadovy de Mitcheson et al., 2013). However, the traditional tools for the control and regulation of fisheries are extremely limited, and the modern methods available for the identification of epinephelid species, such as real-time PCR (Chen et al., 2012; Ulrich et al., 2013) and DNA barcoding which, while effective, demand expensive equipment and laboratory resources. In addition, no molecular identification procedure is currently in use for the detection of the illegal fishing of the Atlantic goliath grouper in Brazil.

Molecular markers used in the multiplex fingerprinting technique for the authentication, control, and inspection of fishery stocks are based on the design of specific oligonucleotides and markers derived from the sequencebased amplification of the 5S, 12S, 18S (Asensio, 2008, Asensio et al., 2009), 16S (Ulrich et al., 2013), Cyt b (Melo Palmeira et al., 2013), and COI genes (Mendonça et al., 2010), as well as fragment length polymorphisms, RFLPs (Paine et al. 2007; Torres et al. 2013) or even nuclear markers, 
such as ITS 2 (Feldheim et al., 2010), SNPs (Torres et al., 2013) and microsatellites (Rodrigues et al., 2011), and realtime PCR techniques (Trotta et al., 2005). The COI gene is a highly effective and reliable tool for the diagnosis of the authenticity of fishery products (Veneza et al., 2014), and the multiplex PCR technique has proven especially effective for the detection of endangered species (Mendonça et al., 2010; De-Franco et al., 2010; Alexandre de-Franco et al., 2012). In this case, the low cost of the synthesis of the specific primers for the epinephelid species developed in the present study, and the simplicity of the multiplex PCR technique may favor the adoption of this more effective method for forensic identification, with the added advantage of providing more precise statistics on the fishery exploitation of the epinephelids along the Brazilian coast.

The diversity of endangered and over-exploited fishes, and the extremely restricted laws that protect them, demand the routine use of forensic genetics by the environmental protection agencies in South America (Barletta et al., 2010). The identification of commercial grouper species using relatively simple, low-cost techniques represents an important contribution to the work of the government organs responsible for the regulation of the fishery industry in tropical and subtropical countries of the western Atlantic.

The adoption of the routine molecular differentiation of grouper species (Epinephelidae) using the multiplex PCR of the COI gene developed may be especially effective for the systematic control, regulation, and management of the commercial fishing of these species, due to its low cost, the rapid acquisition of results, and the relatively simple laboratory facilities needed. As endangered species are rarely found in the samples, they are difficult to detect, thereby increasing the costs of processing a large number of samples with potentially negative results. In this case, the approach may be more appropriate for the initial phases of an investigation, with other methods (PCR-RFLP, real-time $\mathrm{PCR}$, genotyping or sequencing) being used to diagnose the samples more specifically during the subsequent phases of the inspection. This should optimize operating costs and time, and provide greater precision in the analysis of the genetic parameters.

\section{Acknowledgments}

Authors are grateful to the Coordenação de Aperfeiçoamento de Pessoal de Nível Superior (CAPES), the Fundação de Amparo à Pesquisa do Estado de São Paulo (FAPESP), the Fundação de Amparo à Pesquisa do Espírito Santo (FAPES), the Projeto Meros do Brasil, which is supported by Petrobrás S.A. (through the Programa Petrobrás Ambiental) and Transpetro Transportes S.A. for financial support. We would also like to thank Isabela M. Cheida for providing the samples of Epinephelus quinquefasciatus analyzed in this study. The Sistema de Autorização e Informação em Biodiversidade (SISBIO) linked to the Instituto Chico Mendes de Conservação da Biodiversidade (ICMBIO) of the Ministério do Meio Ambiente (MMA) for licenses (SISBIO/ICMBIO/MMA No: 25088-7, authentication code 119228433 and No: 150802, authentication code: 84636263 .

\section{References}

Abercrombie, D. L., S. C. Clarke \& M. S. Shivji. 2005. Global-scale genetic identification of hammerhead sharks: application to assessment of the international fin trade and law enforcement. Conservation Genetics, 6: 775-788.

Alacs, E. A., A. Georges, N. N. FitzSimmons \& J. Robertson. 2010. DNA detective: a review of molecular approaches to wildlife forensics. Forensic Science, Medicine, and Pathology, 6: 180-194.

Alexandre de-Franco, B., F. Fernandes Mendonça, C. Oliveira \& F. Foresti. 2012. Illegal trade of the guitarfish Rhinobatos horkelii on the coasts of central and southern Brazil: genetic identification to aid conservation. Aquatic Conservation: Marine and Freshwater Ecosystems, 22: 272-276.

Aljanabi, S. M. \& I. Martinez. 1997. Universal and rapid saltextraction of high quality genomic DNA for PCR-based techniques. Nucleic Acids Resources, 25: 4692-4693.

Asensio, L. 2008. Application of multiplex PCR for the identification of grouper meals in the restaurant industry. Food Control, 19: 1096-1099.

Asensio, L., I. González, M. Rojas, T. García \& R. Martín. 2009. PCR-based methodology for the authentication of grouper (Epinephelus marginatus) in commercial fish fillets. Food Control, 20: 618-622.

Barletta, M., A. J. Jaureguizar, C. Baigun, N. F. Fontoura, A. A. Agostinho, V. M. F. Almeida-Val, A. L. Val, R. A. Torres, L. F. Jimenes-Segura, T. Giarrizzo, N. N. Fabré, V. S. Batista, C. Lasso, D. C. Taphorn, M. F. Costa, P. T. Chaves, J. P. Vieira, \& M. F. M. Corrêa. 2010. Fish and aquatic habitat conservation in South America: a continental overview with emphasis on neotropical systems. Journal of Fish Biology, 76: 2118-2176.

Baker, C. S. 2008. A truer measure of the market: the molecular ecology of fisheries and wildlife trade. Molecular Ecology, 17: 3985-3998.

Begossi, A., P. Lopes \& R. Silvano. 2012a. Co-Management of reef fisheries of the snapper-grouper complex in a human ecological context in Brazil. Pp. 353-373. In: Kruse, G. H., H. I. Browman, K. L. Cochrane, D. Evans, G. S. Jamieson, P. A. Livingston, D. Woodby \& C. I. Zhang. (Eds.). Global progress in ecosystem-based fisheries management. Alaska Sea Grant, University of Alaska Fairbanks.

Begossi, A., S. V. Salivonchyk, T. Barreto, V. Nora \& R. A. M. Silvano. 2012b. Small-scale fisheries and conservation of drusky grouper (Garoupa), Epinephelus marginatus (Lowe, 1834 ) in the southeastern brazilian coast. Science Journal of Agricultural Research and Management. 2012: 1-4.

Bertoncini, A., M. Borgonha, L. Bueno, M. Freitas, F. Grecco, L. Machado \& M. Hostim-Silva. 2013. Reef fish aggregations in southern Brazil: Pró-Arribada and Meros do Brasil initiatives. Proceedings of the $65^{\text {th }}$ Annual Gulf and Caribbean Fisheries Institute, 65: 287-292. 
Bester-van der Merwe A. E. \& K. S. Gledhill. 2015. Molecular species identification and population genetics of chondrichthyans in South Africa: current challenges, priorities and progress. African Zoology, 50: 1-13.

Carvalho, D. C., R. M. Palhares, M. G. Drummond \& T. B. Frigo. 2015. DNA Barcoding identification of commercialized seafood in south Brazil: a governmental regulatory forensic program. Food Control, 50: 784-788.

Chapman, D. D., D. L. Abercrombie, C. J. Douady, E. K. Pikitch, M. J. Stanhopen \& M. S. Shivji. 2003. A streamlined, biorganelle, multiplex PCR approach to species identification: application to global conservation and trade monitoring of the great white shark, Carcharodon carcharias. Conservation Genetics, 4: 415-425.

Chen, S., J. Zhang, W. Chen, Y. Zhang, J. Wang, D. Xu, Y. Zhou. 2012. Quick method for grouper species identification using real-time PCR. Food Control, 27: 108-112.

Chiappone, M., R. Sluka \& K. S. Sealey. 2000. Groupers (Pisces: Serranidae) in fished and protected areas of the Florida Keys, Bahamas and northern Caribbean. Marine Ecology Progress Series, 198: 261-272.

Coleman, F. C. \& C. C. Koenig. 2010. The effects of fishing, climate change, and other anthropogenic disturbances on red grouper and other reef fishes in the Gulf of Mexico. Integrative and Comparative Biology, 50: 201-212.

Craig, M.T. 2011. Epinephelus itajara. The IUCN Red List of Threatened Species 2011 e.T195409A8961414. http://dx.doi. org/10.2305/IUCN.UK.2011-2.RLTS.T195409A8961414.en. (Date of access - 8 January 2015).

Craig, M. T., R. T. Graham, R. A. Torres, J. R. Hyde, M. O. Freitas, B. P. Ferreira, M. Hostim-Silva, L. C. Gerhardinger, A. A. Bertoncini \& D. R. Robertson. 2009. How many species of goliath grouper are there? Cryptic genetic divergence in a threatened marine fish and the resurrection of a geopolitical species. Endangered Species Research, 7: 167-174.

Craig, M. T. \& P. A. Hastings. 2007. A molecular phylogeny of the groupers of the subfamily Epinephelinae (Serranidae) with a revised classification of the tribe Epinephelini. Ichthyological Research, 54: 1-17.

Craig, M. T., Y. J. Sadovy de Mitcheson \& P. C. Heemstra. 2011. Groupers of the World: a field and market guide. Grahamstown, NISC (Pty) Ltd., 424p.

De-Franco, B., F. F. Mendonça, D. T. Hashimoto, F. PortoForesti, C. Oliveira \& F. Foresti. 2010. Forensic identification of the guitarfish species Rhinobatos horkelli, R. percellens and Zapteryx brevirostris using multiplex-PCR. Molecular Ecology Resources, 10: 197-199.

Edgar, R. C. 2004. MUSCLE: multiple sequence alignment with high accuracy and high throughput. Nucleic Acids Resources, 32: 1792-1797.

Feldheim, K. A., D. D. Chapman, C. A. Simpfendorfer, V. P. Richards, M. S. Shivji, T. R. Wiley, G. R. Poulakis, J. K. Carlson, R. Eng \& S. Sagarese. 2010. Genetic tools to support the conservation of the endangered smalltooth sawfish, Pristis pectinata. Conservation Genetics Resources, 2: 105-113.
Felsenstein, J. 1981. Evolutionary trees from gene frequencies and quantitative characters: finding maximum likelihood estimates. Evolution, 35: 1229-1242.

Francesconi, J. J. \& F. J. Schwartz. 2000. Jewfish, Epinephelus itajara, from North Carolina, with range correction and body comparisons. Journal of the Elisha Mitchell Scientific Society, 116: $167-170$.

Graham, R. T., K. L. Rhode \& D. Castellanos. 2009. Characterization of the goliath grouper Epinephelus itajara fishery of southern Belize for conservation planning. Endangered Species Research, 7: 195-204.

Hashimoto, D. T., F. F. Mendonça, J. A. Senhorini, J. Bortolozzi, C. Oliveira, F. Porto-Foresti \& F. Foresti. 2010. Identification of hybrids between Neotropical fish Leporinus macrocephalus and Leporinus elongatus by PCR-RFLP and multiplex-PCR: tools for genetic monitoring in aquaculture. Aquaculture, 298: 346-349.

Heemstra, P. C. \& J. E. Randall. 1993. FAO species catalogue vol. 16. Groupers of the world (family Serranidae, subfamily Epinephelinae): an annotated and illustrated catalogue of the grouper, rockcod, hind, coral grouper, and lyretail species known to date. FAO Fisheries Synopsis 125, Rome, FAO, $382 \mathrm{p}$.

IBAMA. 2004. Instituto Brasileiro do Meio Ambiente e dos Recursos Naturais Renováveis - Estatística da pesca 2003 Brasil: grandes regiões e unidades da federação / Brasília: Ibama, 2008. 98p. http://www.ibama.gov.br/documentosrecursos-pesqueiros/estatistica-pesqueira (Date of access - 21 December 2014).

IBAMA. 2005. Instituto Brasileiro do Meio Ambiente e dos Recursos Naturais Renováveis - Estatística da pesca 2004 Brasil: grandes regiões e unidades da federação / Brasília: Ibama, 2008. 98p. http://www.ibama.gov.br/documentosrecursos-pesqueiros/estatistica-pesqueira (Date of access - 21 December 2014).

IBAMA. 2007a. Instituto Brasileiro do Meio Ambiente e dos Recursos Naturais Renováveis - Estatística da pesca 2005 Brasil: grandes regiões e unidades da federação / Brasília: Ibama, 2008. 108p. http://www.ibama.gov.br/documentosrecursos-pesqueiros/estatistica-pesqueira (Date of access - 21 December 2014).

IBAMA. 2007b. Instituto Brasileiro do Meio Ambiente e dos Recursos Naturais Renováveis - Estatística da pesca 2007 Brasil: grandes regiões e unidades da federação / Brasília: Ibama, 2008. 113p. http://www.ibama.gov.br/documentosrecursos-pesqueiros/estatistica-pesqueira (Date of access - 21 December 2014).

IBAMA. 2008. Instituto Brasileiro do Meio Ambiente e dos Recursos Naturais Renováveis - Estatística da pesca 2006 Brasil: grandes regiões e unidades da federação / Brasília: Ibama, 2008. 174p. http://www.ibama.gov.br/documentosrecursos-pesqueiros/estatistica-pesqueira (Date of access - 21 December 2014).

IUCN. 2015. The IUCN (International Union for Conservation of Nature) Red List of Threatened Species. Version 2015.2. http://www.iucnredlist.org (Date of access - 27 July 2015). 
Kimura, M. 1980. A simple method for estimating evolutionary rates of base substitutions through comparative studies of nucleotide sequences. Journal of Molecular Evolution, 16: $111-120$

Ma, K. Y. 2014. Patterns and processes of diversification in groupers (family: Epinephelidae). Unpublished $\mathrm{PhD}$ thesis, James Cook University, 203p.

McCauley, D. J., M. L. Pinsky, S. R. Palumbi, J. A. Estes, F. H. Joyce \& R. R. Warner. 2015. Marine defaunation: Animal loss in the global ocean. Science, 347, 1255641.

Melo Palmeira, C. A, L. F. da Silva Rodrigues-Filho, J. B. de Luna Sales, M. Vallinoto, H. Schneider \& I. Sampaio. 2013. Commercialization of a critically endangered species (largetooth sawfish, Pristis perotteti) in fish markets of northern Brazil: authenticity by DNA analysis. Food Control, 34: 249-252.

MPA. 2012a. Boletim estatístico da pesca e aquicultura Brasil 2008-2009 99p. http://www.mpa.gov.br/index.php/ monitoramento-e-controle/informacoes-e-estatisticas (Date of access - 21 December 2014).

MPA. 2012b. Boletim estatístico da pesca e aquicultura - Brasil 2010 128p. http://www.mpa.gov.br/index.php/monitoramentoe-controle/informacoes-e-estatisticas (Date of access - 21 December 2014).

MPA. 2012c. Boletim estatístico da pesca e aquicultura - Brasil 2011 60p. http://www.mpa.gov.br/index.php/monitoramentoe-controle/informacoes-e-estatisticas (Date of access - 21 December 2014).

Mendonça, F. F., D. T. Hashimoto, B. De-Franco, F. PortoForesti, O. B. F. Gadig, C. Oliveira \& F. Foresti. 2010. Genetic identification of lamniform and carcharhiniform sharks using multiplex-PCR. Conservation Genetics Resources, 2: 31-35.

Ogden, R. 2008. Fisheries forensics: the use of DNA tools for improving compliance, traceability and enforcement in the fishing industry. Fish and Fisheries, 9: 462-472.

Paine, M. A., J.R. McDowell \& J. E. Graves. 2007. Specific identification of western Atlantic Ocean scombrids using mitochondrial DNA cytochrome $c$ oxidase subunit I (COI) gene region sequences. Bulletin of Marine Science, 80: 353-367.

Pauly, D., V. Christensen, S. Guénette, T. J. Pitcher, U. R. Sumaila, C. J. Walters, R. Watson \& D. Zeller D. 2002. Towards sustainability in world fisheries. Nature, 418: 689-695.

Ravago-Gotanco, R. G., M. T. Manglicmot \& M. J. R. Pante. 2010. Multiplex PCR and RFLP approaches for identification of rabbitfish (Siganus) species using mitochondrial gene regions. Molecular Ecology Resources, 10: 741-743.

Rodrigues, K. F., S. Shigeharu \& C. L. Ch’Ng. 2011. Microsatellite markers for the identification of commercially important groupers Epinephelus lanceolatus, Cromileptes altivelis and Epinephelus fuscoguttatus. Pertanika Journal Tropical Agricultural Science, 34: 311-315.

Sadovy, Y. J. \& A.M. Eklund. 1999. Synopsis of biological information on the Nassau grouper, Epinephelus striatus, (Bloch 1792), and the jewfish, E. itajara (Lichtenstein 1822). NOAA Technical Report, NMFS 146, and FAO Fisheries Synopsis 157. $65 \mathrm{p}$.
Sadovy de Mitcheson, Y., M. T. Craig, A. A. Bertoncini, K. E. Carpenter, W. W. L. Cheung, J. H. Choat, A. S. Cornish, S. T. Fennessy, B. P. Ferreira, P. C. Heemstra, M. Liu, R. F. Myers, D. A. Pollard, K. L. Rhodes, L. A. Rocha, B. C. Russell, M. A. Samoilys \& J. Sanciangco. 2013. Fishing groupers towards extinction: a global assessment of threats and extinction risks in a billion dollar fishery. Fish and Fisheries, 14:119-136.

Shivji, M., S. Clarke, M. Pank, L. Natanson, N. Kohler \& M. Stanhope. 2002. Genetic identification of pelagic shark body parts for conservation and trade monitoring. Conservation Biology, 16: 1036-1047.

Song, H., J. E. Buhay, M. F. Whiting \& K. A. Crandall. 2008. Many species in one: DNA barcoding overestimates the number of species when nuclear mitochondrial pseudogenes are coamplified. PNAS: Proceedings of the National Academy of Sciences of the United State of America, 105: 13486-13491.

Tamura, K., D. Peterson, N. Peterson, G. Stecher, M. Nei \& S. Kumar. 2011. MEGA 5: molecular evolutionary genetics analysis using maximum likehood, evolutionary distance and maximum parsimony methods. Molecular Biology and Evolution, 28: 2731-2739.

Teletchea, F. 2009. Molecular identification methods of fish species: reassessment and possible applications. Reviews in Fish Biology and Fisheries, 19: 265-293.

Torres, R.A., R. B. Feitosa, D. C. Carvalho, M. O. Freitas, M. Hostim-Silva \& B. P. Ferreira. 2013. DNA barcoding approaches for fishing authentication of exploited grouper species including the endangered and legally protected goliath grouper Epinephelus itajara. Scientia Marina, 77: 409-418.

Trotta, M., S. Schönhuth, T. Pepe, M. L. Cortesi, A. Puyet \& J. M. Bautista. 2005. Multiplex PCR method for use in real-time pcr for identification of fish fillets from grouper (Epinephelus and Mycteroperca species) and common substitute species. Journal of Agricultural and Food Chemistry, 53: 2039-2045.

Ulrich, R. M., D. E. John, G. W. Barton, G. S. Hendrick, D. P. Fries \& J. H. Paul. 2013. Ensuring seafood identity: grouper identification by real-time nucleic acid sequence-based amplification (RT-NASBA). Food Control, 31: 337-344.

Veneza, I., B. Felipe, J. Oliveira, R. Silva, I. Sampaio, H. Schneider $\&$ G. Gomes. 2014. A barcode for the authentication of the snappers (Lutjanidae) of the western Atlantic: rDNA 5S or mitochondrial COI? Food Control, 38: 116-123.

Ward, R. D., T. S. Zemlak, B. H. Innes, P. R. Last \& P. D. N. Hebert. 2005. DNA barcoding Australia's fish species. Philosophical Transactions of the Royal Society of London Series B, 360: 1847-1857. 